\title{
Cutaneous metastasis in adenocarcinoma rectum
}

\author{
Sundeep Malla, ${ }^{\oplus}$ Abdul Razik, Surabhi Vyas
}

Radiodiagnosis, All India Institute of Medical Sciences, New Delhi, Delhi, India

\section{Correspondence to}

Dr Surabhi Vyas,

surabhi_vyas@yahoo.com

Accepted 20 March 2019

\section{Check for updates}

(c) BMJ Publishing Group Limited 2019. No commercial re-use. See rights and permissions. Published by BMJ.

To cite: Malla S, Razik A, Vyas S. BMJ Case Rep

2019:12:e229652

doi:10.1136/bcr-2019229652

\section{DESCRIPTION}

A 35 -year-old male patient, a known case of mucinous adenocarcinoma rectum, who had undergone laparoscopic abdominoperineal resection 2 months back, presented with multiple well-defined, firm, nodular skin lesions distributed over the face, chest, abdomen and back, along with epigastric pain over a period of 1 month (figure $1 \mathrm{~A}, \mathrm{~B}$ ). The patient had been advised capecitabine and oxaliplatin regimen as adjuvant chemotherapy after the surgery, which he refused. In view of the clinical history, a provisional diagnosis of cutaneous metastasis was made. Contrast-enhanced CT of the abdomen showed two large, solid-cystic lesions in the left lobe of liver and multiple cutaneous, subcutaneous, intramuscular as well as intraperitoneal solid-cystic lesions in the abdominal wall, some showing calcification (figure 1C). Biopsy of one of the cutaneous lesions showed mucinous adenocarcinoma metastasis. $\mathrm{He}$ refused palliative chemotherapy and ultimately succumbed 3 months later.

Cutaneous metastasis is rare, with carcinoma lung being the most common cause. It occurs in about $6 \%$ of patients with colorectal cancer, the abdominal wall being the most common site. Cutaneous spread usually occurs through venous as well as lymphatic dissemination and is often detected several years after the surgical removal of the primary tumour, the mean interval being 33 months. ${ }^{23}$ Mucinous histology has been associated with the highest incidence of cutaneous metastasis. ${ }^{4}$
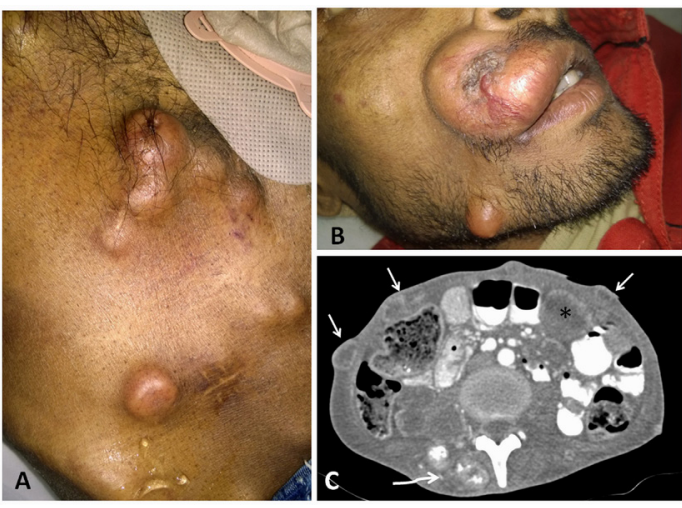

Figure 1 (A) Clinical photograph of the abdomen showing multiple, well-defined, firm, nodular skin lesions adjacent to the stoma site. (B) Clinical photograph of the face showing multiple similar nodular skin lesions. (C) Axial contrast-enhanced CT of the abdomen showing multiple, well-defined enhancing cutaneous and subcutaneous (arrows), intramuscular (curved arrow) as well as intraperitoneal (asterisk) lesions, some showing calcification.

\section{Patient's perspective}

My husband was diagnosed with cancer of the rectum. We were devastated. Finally, he underwent chemotherapy and radiotherapy and subsequently underwent surgery. We were very happy and thought that all our problems were over. Few months after the surgery, he developed a few swellings in skin on face and abdomen. We visited our doctor, and he conducted multiple tests and said that the cancer had spread to the skin. He was given chemotherapy but his health deteriorated, and he passed away a couple of months later. It was a horrible experience for me.

\section{Learning points}

- Any cutaneous nodule in a postoperative case of adenocarcinoma rectum should be thoroughly evaluated as it may be the earliest sign of recurrence.

- Cutaneous metastasis is usually a sign of distant dissemination, and such patients carry a poor prognosis.

It may be the first sign of recurrence in operated cases of carcinoma rectum and signifies a poor prognosis. ${ }^{5}$ Hence, a thorough evaluation of any new skin nodule in such patients is mandatory.

Contributors SM wrote the preliminary draft. AR and SV edited the draft and gave further scientific inputs.

Funding The authors have not declared a specific grant for this research from any funding agency in the public, commercial or not-for-profit sectors.

Competing interests None declared.

Patient consent for publication Next of kin consent obtained. Provenance and peer review Not commissioned; externally peer reviewed.

\section{REFERENCES}

1 Saeed S, Keehn CA, Morgan MB. Cutaneous metastasis: a clinical, pathological, and immunohistochemical appraisal. J Cutan Pathol 2004;31:419-30.

2 Lookingbill DP, Spangler N, Helm KF. Cutaneous metastases in patients with metastatic carcinoma: a retrospective study of 4020 patients. J Am Acad Dermatol 1993;29(2 Pt 1):228-36.

3 Kauffman CL, Sina B. Metastatic inflammatory carcinoma of the rectum: tumor spread by three routes. Am J Dermatopathol 1997:19:528-32.

4 Dehal A, Patel S, Kim S, et al. Cutaneous metastasis of rectal cancer: A case report and literature review. Perm J 2016;20:74-8.

5. Hashimi Y, Dholakia S. Facial cutaneous metastasis of colorectal adenocarcinoma. BMJ Case Rep 2013;2013. doi: bcr2013009875 https://www.ncbi.nlm.nih.gov/pmc/articles/PMC3822271/. 
Images in...

Copyright 2019 BMJ Publishing Group. All rights reserved. For permission to reuse any of this content visit https://www.bmj.com/company/products-services/rights-and-licensing/permissions/

BMJ Case Report Fellows may re-use this article for personal use and teaching without any further permission.

Become a Fellow of BMJ Case Reports today and you can:

- Submit as many cases as you like

- Enjoy fast sympathetic peer review and rapid publication of accepted articles

Access all the published articles

- Re-use any of the published material for personal use and teaching without further permission

For information on Institutional Fellowships contact consortiasales@bmjgroup.com

Visit casereports.bmj.com for more articles like this and to become a Fellow 